\title{
THE RUSSIAN HIGHER EDUCATION EXPORT AS A TOOL FOR THE COMPETITIVENESS IMPROVEMENT OF A COUNTRY GLOBALLY
}

\author{
Ekaterina Novikova \\ Assoc. Prof., PhD, Plekhanov Russian University of Economics, Russia, eknov1981@gmail.com
}

\begin{abstract}
This research paper includes the analysis of the Russian higher education system and opportunities for its export as a tool for the competitiveness improvement of a country globally. This statement is considered in the paper taking into account the latest changes in the global economy including digitalization, automation, economic crisis with trading wars and other phenomena. Additionally, the flows of foreign students have been studied within different period of time taking into account countries of origin for students. Statistical data on students flows have been compared with the situation in other countries and corresponded conclusions have been provided.
\end{abstract}

Keywords: Higher education, export, competitiveness, import substitution, human resources, brain drain, technological progress, market economy

\section{INTRODUCTION}

Nowadays the competitiveness for human resources in the international division of labor has been intensified more than ever. The whole rate of accumulated problems and trends in the global society has contributed to this. First, a renewed outbreak in the technological development of humanity leads to the global digitalization and automation both production capacity and services. Such change has led to the global displacement for a large number of professions with low demand at the market. At the same time requirements to the level of education, quality of knowledge and skills of specialists have increased dramatically [2].

Simultaneously, the technological changes have led to additional opportunities in the attraction of foreign citizens as a students for professional education at the coordinated market with following opportunities: education and employment in the same country; employment in its own country in the cooperation with companies from a country, where education has been passed; and additionally, the employment in the third country, where the influence of a country provided the education has the key role [8].

Thus, we have the "brain drain" process from Russia to Western countries, at the same time there is a goal to attract foreign citizens from other regions into Russia, for example from China, India, Vietnam, countries of former Soviet Union, etc. [7] Such selection of countries has been created by means of existing trade relations between countries, and therefore lies in the goal of education for its citizens in accordance with modern knowledge and skills attracted by this market and special tendencies. Thus, the sector of educational services is a tool of a soft power in the process of influence on other countries, and in the creation of the most perspective markets for launching products of their companies.

Described above phenomenon has appeared also in the Russian economy after Soviet Union collapse, 
when the majority of Russian students have been attracted by Western universities for corresponded education and formation of "market" mentality for further launch of market ideas in Russia. A system of consumption economy at the national market and the increased level of dependence on import products is the result of such process for last decades. Only for last five years, there are some attempts to get rid of such high-level dependence on foreign products by import substitution policy.

The attraction of young human resources from other countries is also a target for most of developed western countries in order to create additional consumer demand in its internal markets. As we can see, the revision of already existed markets is in the process as reflected in sanction policy some countries against another ones, and in the trading wars of the whole regions.

Thus, the role of human resources increases exponentially, and the level of countries' competitiveness is evaluated by number of graduates with the most demanded positions in terms of technological progress, annual number of patents by countries, number of researchers among the whole population of a country, etc.

For example, in accordance with the World bank data, the human capital in Russia estimates only in $46 \%$ of the whole accumulated capital, at the same time the productive capital represents $33 \%$, natural capital $20 \%$, and net foreign assets only $1 \%$. There is a need to outline that the share of human capital in the wealth of Russia in $24 \%$ less than in average for OECD countries with $70 \%$ in accordance with statistics [1].

Based on that, the problem has raised how Russia could achieve higher and more competitive indicators in the field of human capital in the nearest future for further definition of its role in the international division of labor.

\section{ANALYSIS}

This problem is multivariate and cannot be solved by means of one or two initiatives from the side of the Russian government. This requires structural reforms in the creation of new approach with the purpose of human resources development. One of such initiatives is the attraction of foreign students in the Russian universities in the nearest several years. Because of such project realization, the number of foreign students was 220 thousand people in year 2017 and can be increased up to 710 thousand people in year 2025. At the same time the number of participants for online courses in Russian universities can increase from 1,1 mln people up to $3,5 \mathrm{mln}$ people in year 2025 [3]. Taking into account the planned growth in the number of foreign students, the government revenue can be increased up to 370 bln rubles in year 2025 by export of the Russian education. Based on this planned program of the Russian government, 39 state universities are the leading platforms in the attraction of foreign students in different sectors of economy [5,9].

There is a plan to spend approximately 800 bln rubles for the realization of this project. The first instalment has been provided in year 2019 in the volume of 11,72 bln rubles as pilot money transfer (Figure 1). [9]

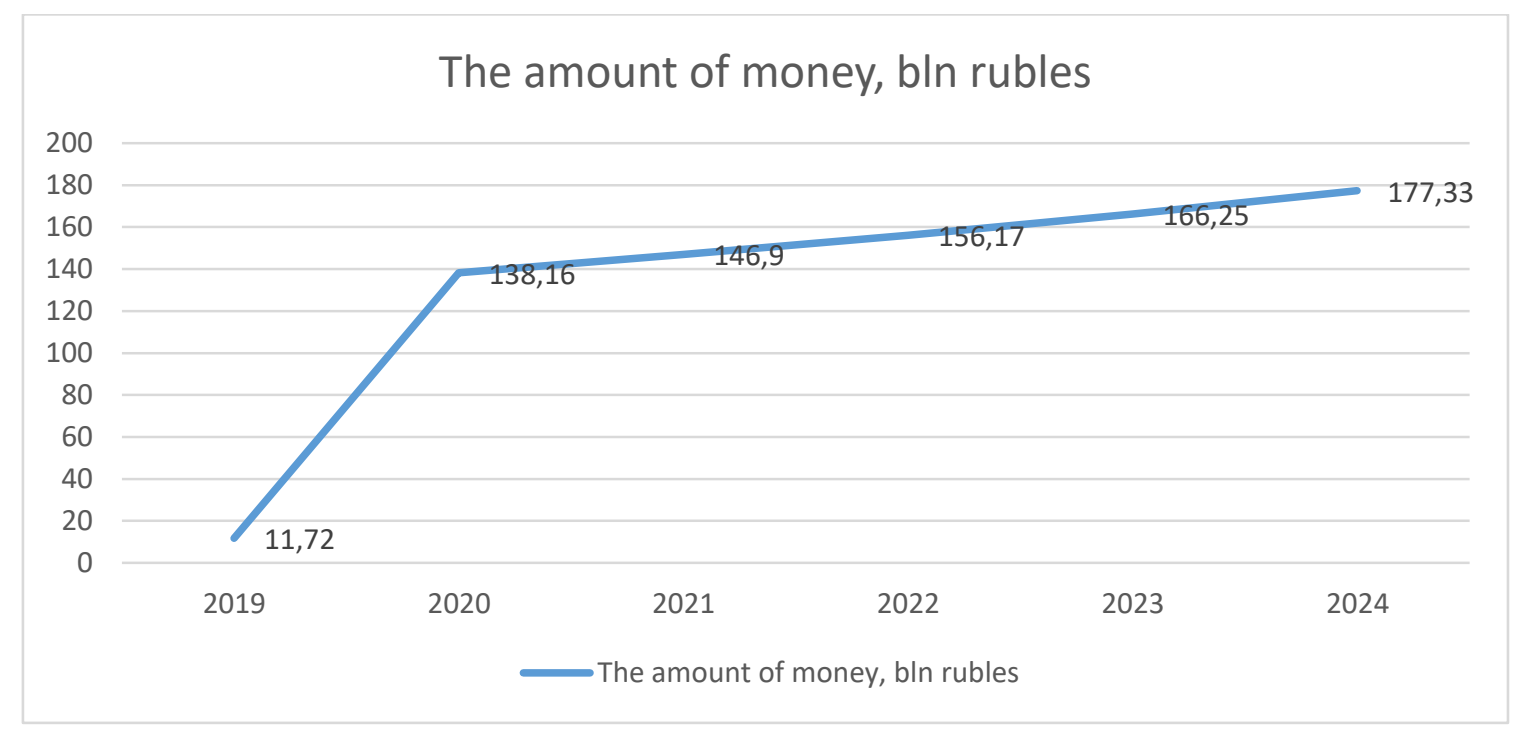

This support includes additional budget places for the attraction of talented foreign students, English courses and other foreign languages, scholarships for online courses development, university infrastructure development, etc. Thus, the number of foreign students should increase in accordance with mentioned above plan in the nearest five years. 
In order to promote the policy of foreign students' attraction in the Russian universities, this is important to analyze historical changes in the export of the Russian education both in Soviet time and in the last decade.

The number of foreign students studied in Soviet universities over the 1950 to 1991 period has increased from 5,9 to 126,5 thousand people or from $0,5 \%$ to $2,6 \%$ in accordance with statistics.

Table 1. Dynamics in the number of foreign students, studied in Soviet universities in the period 1950/1951 1990/1991 academic years [4]

\begin{tabular}{|l|l|l|l|}
\hline Years & $\begin{array}{l}\text { Number of foreign } \\
\text { students, studied in } \\
\text { Soviet universities, } \\
\text { thousand people }\end{array}$ & $\begin{array}{l}\text { General number of } \\
\text { students in Soviet } \\
\text { universities, thousand } \\
\text { people }\end{array}$ & $\begin{array}{l}\text { Share of foreign } \\
\text { students among all } \\
\text { students in Soviet } \\
\text { universities, \% }\end{array}$ \\
\hline $1950 / 1951$ & 5,9 & 1246 & 0,5 \\
\hline $1960 / 1961$ & 13,5 & 1396,1 & 0,6 \\
\hline $1970 / 1971$ & 25,6 & 4580,6 & 0,6 \\
\hline $1980 / 1981$ & 88,3 & 5235,2 & 1,7 \\
\hline $1990 / 1991$ & 126,5 & 4853 & 2,6 \\
\hline
\end{tabular}

Taking into account the export of educational services in the global scale, the share of foreign students in Soviet universities to the global number of foreign students has been increase from 5,4\% to 10,8\% (Table 2 ).

Table 2. The tendency in the number of foreign students in Soviet universities in the period of 1950/1951 $1990 / 1991$ academic years in comparison with global number of foreign students [4]

\begin{tabular}{|l|l|l|l|}
\hline Years & $\begin{array}{l}\text { Global number of } \\
\text { foreign students, } \\
\text { thousand people }\end{array}$ & $\begin{array}{l}\text { Number of foreign } \\
\text { students in Soviet } \\
\text { universities, thousand } \\
\text { people }\end{array}$ & $\begin{array}{l}\text { Share of foreign } \\
\text { students in Soviet } \\
\text { universities in the } \\
\text { comparison with global } \\
\text { number of foreign } \\
\text { students, \% }\end{array}$ \\
\hline $1950 / 1951$ & 110 & 5,9 & 5,4 \\
\hline $1960 / 1961$ & 231,4 & 13,5 & 5,8 \\
\hline $1970 / 1971$ & 447,8 & 25,6 & 5,9 \\
\hline $1980 / 1981$ & 915,8 & 88,3 & 9,6 \\
\hline $1990 / 1991$ & 1168,1 & 126,5 & 10,8 \\
\hline
\end{tabular}

The greatest number of foreign students graduated from Soviet universities for this period of time was originally from East-European region (72522 thousand people), and Asian countries (58516 thousand people) (Figure 2).

At the same time the greatest number of foreign students in the academic year 1990/1991 in Soviet universities were from Mongolia, Vietnam, Afghanistan, Cube, Bulgaria, Syria, Yemen, Ethiopia and Libya (Table 3). 


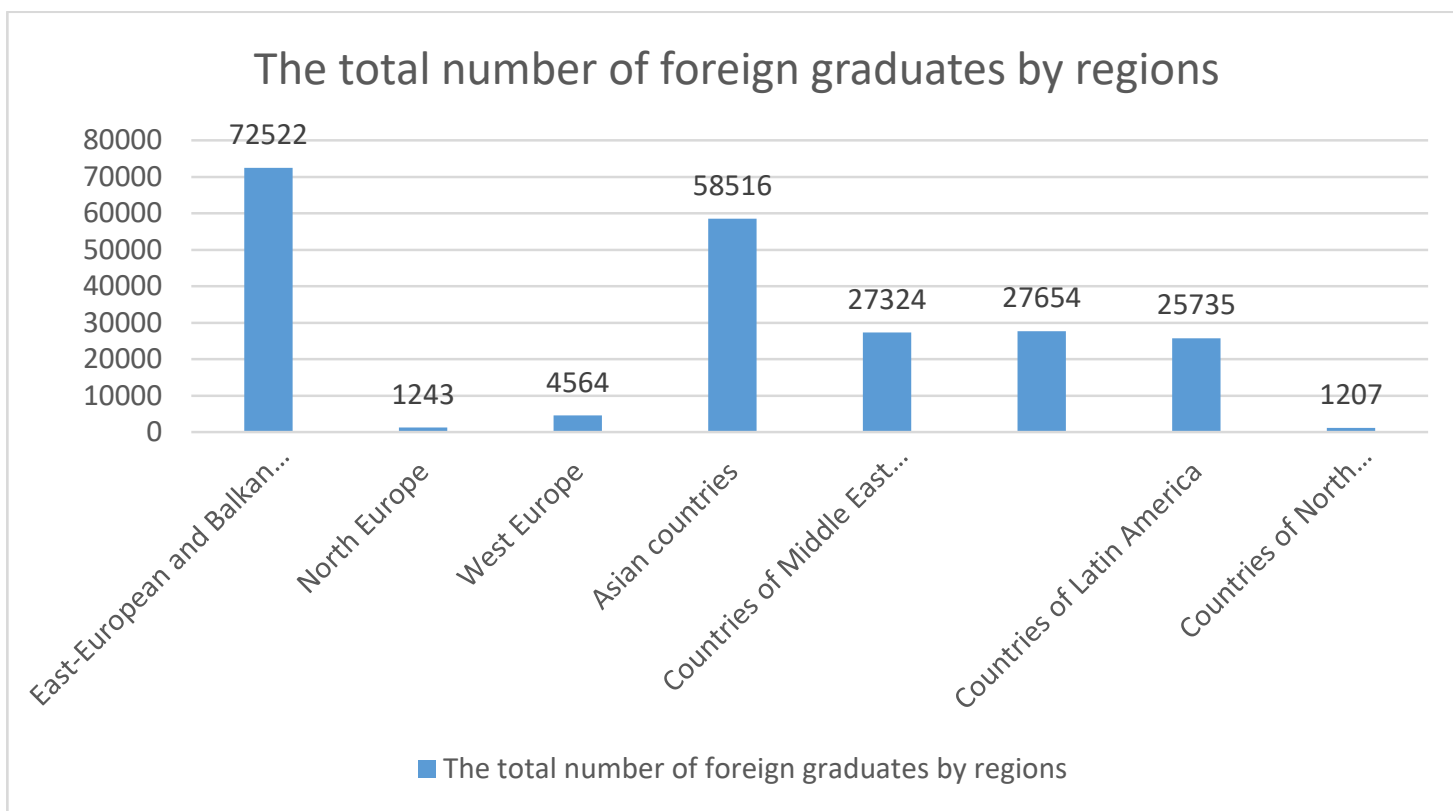

Figure 2. The total number of foreign students graduated from Soviet universities in 1950/1951 - 1985/1986 academic years by countries of origin [4]

Table 3. The greatest number of students in Soviet universities in 1990/1991 academic year by countries of origin [4]

\begin{tabular}{|l|l|}
\hline Country & $\begin{array}{l}\text { The greatest number of students in Soviet } \\
\text { universities by countries of origin, thousand } \\
\text { people }\end{array}$ \\
\hline Mongolia & 8,8 \\
\hline Vietnam & 6,7 \\
\hline Afghanistan & 6,1 \\
\hline Cube & 6,1 \\
\hline Болгария & 5,4 \\
\hline Сирия & 5,0 \\
\hline Үетеп & 3,6 \\
\hline Эфиопия & 3,5 \\
\hline Ливан & 3,4 \\
\hline
\end{tabular}

Thus, the number of foreign students in the Russian universities within 2016/2017 academic year has been increased up to 313 thousand people, which is around $7 \%$ of the whole number od students in Russia (Table 4).

Table 4. The dynamics of foreign students' number in the Russian universities for 1950/1951- 2016/2017 academic years and its share in the total number of students in the Russian universities [4]

\begin{tabular}{|l|l|l|l|}
\hline Years & $\begin{array}{l}\text { Number of foreign } \\
\text { students in the Russian } \\
\text { universities, thousand }\end{array}$ & $\begin{array}{l}\text { Total number of } \\
\text { students in the Russian } \\
\text { universities, thousand }\end{array}$ & $\begin{array}{l}\text { The share of foreign } \\
\text { students to the total } \\
\text { number of students in }\end{array}$ \\
\hline
\end{tabular}


Proceedings of ADVED 2020- 6th International Conference on Advances in Education 5-6 October 2020

\begin{tabular}{|l|l|l|l|}
\hline & people & people & $\begin{array}{l}\text { the Russian } \\
\text { universities, } \%\end{array}$ \\
\hline $1950 / 1951$ & 5,2 & 796,7 & 0,65 \\
\hline $1960 / 1961$ & 10,9 & 1496,7 & 0,73 \\
\hline $1970 / 1971$ & 20,7 & 2671,7 & 0,77 \\
\hline $1980 / 1981$ & 64,5 & 3045,8 & 2,12 \\
\hline $1990 / 1991$ & 89,6 & 2824,5 & 3,17 \\
\hline $2000 / 2001$ & 72,4 & 4741,4 & 1,53 \\
\hline $2005 / 2006$ & 113,8 & 7064,6 & 1,61 \\
\hline $2006 / 2007$ & 126,2 & 7341,4 & 1,72 \\
\hline $2007 / 2008$ & 147,6 & 7461,3 & 1,97 \\
\hline $2008 / 2009$ & 166,4 & 7513,1 & 2,21 \\
\hline $2009 / 2010$ & 175,6 & 7419 & 2,36 \\
\hline $2010 / 2011$ & 187,3 & 7049,8 & 2,65 \\
\hline $2011 / 2012$ & 198,5 & 6490 & 3,05 \\
\hline $2012 / 2013$ & 225 & 6075 & 3,70 \\
\hline $2013 / 2014$ & 250,2 & 5647 & 4,43 \\
\hline $2014 / 2015$ & 282,9 & 5209 & 7,43 \\
\hline $2015 / 2016$ & 296,2 & 4399,5 & 7,11 \\
\hline $2016 / 2017$ & 313,1 & & \\
\hline
\end{tabular}

\section{CONCLUSIONS}

In accordance with the latest data, Russia is among six countries, which are the most attractive for foreign students. USA is at the first position with more than a half of global student mobility or $19 \%$, UK is at the second position with $8 \%$, Australia is at the third position with $7 \%$, and finally, France, Germany and Russia have $5 \%$ per each country [10].

The most demanded specializations for foreign students in Russia are engineering and technical (22\%), medicine (20\%), economic and management (39\%), legal issues (10\%) and social sciences (9\%) [6]. The state program for the attraction of foreign students provides first results, and the Russian economy will be able to attract additional money from the program of educational services export. At the same time the synergy effect is the additional surplus for the Russian economy, which is not mentioned in this research paper.

\section{REFERENCE LIST}

1) Belyakov S., Krasnova G., Export of higher education: status and perspectives in Russia and in the world, 
University management: practice and analysis, №6, 2016, https://doi.org/10.15826/umj.2016.106.056

2) Chaykovskaya, L.A., Turishcheva, T. B. and Akhmadeev R. G. (2020). Functional application of the internal control system in autonomous institutions. Bulletin of the National Academy of Sciences of the Republic of Kazakhstan. vol. 1 (383), p. 163 - 171.

3) Education at a Glance, OECD Indicators, 2019

4) Export of the Russian educational services, Statistical textbook, Issue 8, Moscow, 2018

5) Golubtsova, E.V. and Zvereva, A.O. (2019) Development of Tax Attractiveness of Russia's Special Administrative Areas with Fair Tax Competition. Proceedings of the 34th International Business Information Management Association Conference, IBIMA 2019: Education Excellence and Management of Innovations through Sustainable Economic Competitive Advantage Vision 2025, p. 2023- 2028

6) Korableva, O. N., Kalimullina, O. V. and Mityakova, V. N. (2018). Innovation activity data processing and aggregation based on ontological modelling. Paper presented at the 2018 4th International Conference on Information Management, ICIM 2018, p. 1-4.

7) Lehoux, L., Morozova, T.V., Safonova, E.G., Balashova, A.D. and Protasov, M.V. (2019) Practical Aspects in Calculating of Impairment of Financial Assets According to IFRS 9 "Financial Instruments". Proceedings of the 33rd International Business Information Management Association Conference, IBIMA 2019: Education Excellence and Innovation Management through Vision 2020, p. 6624-6632.

8) Novikova E., The impact of digitalization on the competitiveness of the Russian economy with additional investment resources, Problems and perspectives of the Russian development, Moscow, 2019, pp.521-527

9) Project of the competitiveness improvement for the leading Russian universities among the best world scientific and educational centers, Ministry of science and higher education of Russia, 2018

10) Turishcheva, T.B. and Shugurova, S.A. (2019) Actual Aspects of Formation of Accounting Policies for Taxation Purposes of Commercial Organizations. Proceedings of the 34th International Business Information Management Association Conference, IBIMA 2019: Education Excellence and Management of Innovations through Sustainable Economic Competitive Advantage Vision 2025, p.4893-4898 